\title{
Ovarian Tuberculosis in a Developing Community
}

\author{
Wilson I B Onuigbo* \\ Department of Pathology, Medical Foundation \& Clinic, Nigeria
}

Submission: March 27, 2018; Published: May 18, 2018

*Corresponding author: Wilson I B Onuigbo, Department of Pathology, Medical Foundation \& Clinic, Nigeria; Email: wilson.onuigbo@gmail.com

Abstract

From North East Nigeria, a recent study reported a patient whose ovarian tuberculosis masqueraded as ovarian cancer in association with HIV infection. Therefore, 4 cases are documented here in respect of the South East Region of this developing country. The lesion is discussed with reference to countries as far apart as India, Iran, Madagascar and Pakistan. All point to the remedial action of antituberculous drugs as well as the need for developing national guidelines so as to avoid unnecessary laparotomies.

Keywords: Ovary; Tuberculosis; Drug therapy; Developing communities; laparotomies; Ovarian tuberculosis; Ovarian cancer; Epidemiological analysis; Secondary infertility; Malignancy; Masquerading of cancer; HIV infection; Immigration; Ethnic group; Pathologist; Biopsy specimens; Enugu; Birmingham; Central laboratory; Epidemiological analysis

\section{Introduction}

Recently, researchers based in Maiduguri, North Eastern Nigeria, reported a 35-year-old HIV-1 positive housewife, who turned out to have ovarian tuberculosis masquerading as ovarian cancer [1]. Therefore, the present report comes from the South Eastern part of the country with special reference to the ethnic group called the Ibo/Igbos [2]. There are 4 local cases and their presentation is compared with those from India [3-5], Iran [6,7], Madagascar [8] and Pakistan [9]. In this context, discussing them all is deemed to be worthy of documentation.

\section{Investigation}

The Birmingham(UK) group postulated that theestablishment of a histopathology data pool improves epidemiological analysis [10]. Now, it so happened that I became the pioneer pathologist at Enugu, South Eastern Nigeria, from 1970, at the Regional Reference Laboratory. Therefore, since I emphasized that biopsy specimens must be accompanied by adequate epidemiological data, their analysis was relatively simple using the tabular form.

\section{Results}

At a glance, all were right-sided curiously. Apart from Enugu, the rest were received from distant towns. Half of the presentation was to secondary infertility and the other half to the masquerading of cancer. As the ages ranged from 24 to 35 years, the average was 31 years.

\section{Discussion}

The above 31 years average is near to the 35 years of the fellow northern Nigerian [1]. Her illness was not due to HIV infection like the Northerner. Elsewhere, the relative young ages of the sufferers was reported from India [3-5]. Indeed, other countries could be mentioned, namely, those in Asia, the Middle East, and Latin America as being immigration sources of this problem, this being a contribution from an Iranian group [6]. Madagascar also falls into this picture [7].

Two of the local cases which cropped up were because of secondary infertility. In contrast, Pakistan cases involved 2 unmarried women aged 20 and 31 years respectively [8]. Indeed, a welcome conclusion came from that country, namely, "Clear guidelines should be developed nationally owing to the high prevalence of tuberculosis in our country to avoid unnecessary laparotomies."

Incidentally, this series illustrates something of national importance. It rests on the Birmingham (UK) group's postulates that the establishment of a histopathology data pool enhances epidemiological analysis [9]. Such a pool made it possible to contribute this paper personally. Indeed, much as some debated in UK the usefulness of a central laboratory to distant doctors [10], Table 1 shows that only one case emanated from Enugu, the remaining three towns being distant. This compares favorably with my reported experience $[11,12]$.

Table 1: Epidemiological data on ovarian tuberculosis.

\begin{tabular}{|c|c|c|c|c|c|}
\hline No & Initials & Age & Side & Town & $\begin{array}{c}\text { Provisional } \\
\text { Diagnosis }\end{array}$ \\
\hline 1 & IC & 24 & $\mathrm{R}$ & Umuahia & $\begin{array}{c}\text { Secondary } \\
\text { infertility }\end{array}$ \\
\hline 2 & ON & 28 & $\mathrm{R}$ & Aba & $\begin{array}{c}\text { Secondary } \\
\text { infertility }\end{array}$ \\
\hline 3 & NC & 35 & $\mathrm{R}$ & Owerri & Malignancy \\
\hline 4 & NR & 37 & $\mathrm{R}$ & Enugu & Cancer \\
\hline
\end{tabular}




\section{References}

1. Denue BA, Kwayabura SA, Ngadda HA (2014) Ovarian tuberculosis masquerading as ovarian cancer in HIV infection patient: A plea to avoid unnecessary surgery. Pan Af Med J 19: 210.

2. Basden GT (1996) Niger Ibos. Lond: Cass.

3. Wotsa KS, Balamurugan C, Venkatesh G, Beulah P, Vignesh M ( (2015) Isolated ovarian tuberculosis mimicking ovarian carcinoma. Stanley Med J 2(3): 1-2.

4. Gill MK, Bains SPS, Rana S (2015) Isolated ovarian tuberculosis: Case report and literature review. Int J Health Allied Sci 4: 36-38.

5. Roy SL, Devi DRG, sujini BK (2016) Tubo-ovarian mass-A rare case of mycobacterium tuberculosis infection. Int J Curr Microbiol App Sci 5(5): 826-828.

6. Hasanzadeh M, Naderi HR, Hoshyar AH, et al. (2014) Female genital tract tuberculosis presenting as ovarian cancer. J Res Med Sci 19(2): 184-189.

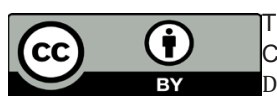

This work is licensed under Creative Commons Attribution 4.0 License

OI: $10.19080 /$ GJORM.2018.04.555643
7. Yassaee F, Farzaneh F (2009) Familial tuberculosis mimicking advanced ovarian cancer. Infect Dis Obstet Gynecol doi: 10.1155/2009/736018.

8. Rabesalama S, Mandeville K, Raherison R, Rakoto-Ratsimba H (2011) Isolated ovarian tuberculosis mimicking ovarian carcinoma: Case report and literature review. Afr J Infect Dis 5(1): 7-10.

9. Akhtar N, Hayat Z, Nazin F (2017) Genital tuberculosis mimicking carcinoma ovary: Can ultrasound guided biopsy be a resolution!. J Avub Med Coll Abbottabad 29(3): 496-498.

10. Macartney JC, Rollaston TP, Codling BW (1980) Use of a histopathology data pool for epidemiological analysis. J Clin Pathol 33(4): 351-353.

11. Lilleyman J (2002) From the President. Bull Roy Coll Pathol 117: 2-3.

12. Onuigbo WIB, Mbanaso AU (2005) Urban histopathology service for a remote Nigerian hospital. Bull Roy Coll Pathol 132: 32-34.

\section{Your next submission with Juniper Publishers will reach you the below assets}

- Quality Editorial service

- Swift Peer Review

- Reprints availability

- E-prints Service

- Manuscript Podcast for convenient understanding

- Global attainment for your research

- Manuscript accessibility in different formats

( Pdf, E-pub, Full Text, Audio)

- Unceasing customer service

Track the below URL for one-step submission

https://juniperpublishers.com/online-submission.php 